\title{
PVC - clay nanocomposites: Preparation, mechanical and thermal properties
}

\author{
E. M. Sadak*¹ , D. El-Komy ${ }^{1}$, A. M. Motawie ${ }^{1}$, M.S.Darwish ${ }^{1}$, S. M. Ahmed ${ }^{1}$, S. M. \\ Mokhtar $^{2}$ \\ ${ }^{1}$ Petrochemical Department, Egyptian Petroleum Research Institute (EPRI), Nasr City, Cairo, \\ Egypt ${ }^{2}$ Chemistry Department, Faculty of Women, Ain Shams University, Cairo, Egypt.
}

\begin{abstract}
:
Poly (vinyl chloride) (PVC) nanocomposite have been prepared via solution technique. The nanocomposite structure based on the used modifier type and content was characterized with (XRD), (TEM) and (FTIR) spectroscopy. The results indicate the interaction of PVC into the clay layers giving an exfoliated PVC nanocomposites. FTIR data of the composites did not show any remarkable change in PVC. The influence of the modifier content (i.e. 1, 2, 3, 4, 5, and 6 wt $\%$ ) and type on the PVC was tested through physico-mechanical properties and thermal stability. The study demonstrated improved mechanical properties and thermal stability for the PVC/ carboxylated salts (3 wt \%) composites compared with those of octadecyl amine (ODA) at the same loading. PVC/clay-ODA composite had worse thermal stability than that of unfilled PVC. Incorporation adipate acid salt (3\%) results in a significant improvement of the thermal stability of PVC at $800^{\circ} \mathrm{C}$.
\end{abstract}

Key words: PVC nanocomposites, organoclay, sodium salts of adipic and sebacic acids, mechanical and thermal properties.

\section{Introduction}

Numerous studies have shown that the introduction of nanoclay into a polymeric matrix can provide a wide range of property enhancements, such as increased composite stiffness and strength, enhanced gas barrier properties, improved flam retardancy, and reduced smoke generation compared to the virgin polymer and conventional composites. These improvements are obtained at significantly lower loading level than those of traditional fillers (Cui et al., 2015; Guo et al., 2018; Istrate and Chen, 2018; Liu et al., 2012; Motawie et al., 2014; Zhu et al., 2019).

One of the most common nanofillers is bentonite (Montmorillonite) a layered silicate clay with several benefits such as cost efficiency and friendliness has been widely used as reinforcement filler of polymers due to its unique structure and reactivity together with high strength, stiffness, swelling, behavior, and large surface area (Motawiea et al., 2015; Sadek et al., 2018, 2015).Poly (vinyl chloride) (PVC), as an important commercial thermoplastic, has been studied and widely used in the industrial field for many years. However because of its inherent disadvantages, such as low thermal stability and brittleness, PVC and its composites are subject to some limitations in certain applications.

*Correspondence to: E. M. Sadek; e-mail: elham_sadek@hotmail.com 
Recently, the development of the polymer layered silicate nanocomposites may present a new way to improve the performance of PVC (Deka et al., 2011; Mansour et al., 2011; Moghri et al., 2017, 2015; A.M. Motawie et al., 2014; Sadek et al., 2014)

Various studies have shown that, selection of organic modifier(Sterky et al., 2010), premixing with plasticizer (Weiss, 2005)or premixing with another polymer (e.g. EVA, TPU or PMMA)(Bakar et al., 2015; Liu et al., 2011 are able to minimize the extent of PVC degradation.

In practice, polymer-clay nanocomposites manufacture based on alkyl ammonium or alkyl phosphonium salts as organo clay is limited. Because these compounds are used in the detergent and cosmetic industries. The alkyl ammonium salts are not suitable for high temperature melt processing techniques, they decompose above $170^{\circ} \mathrm{C}$ with undesirable properties. Dissolution of phosphonium salts in water is quite low, so the removal of remainder salts by water is difficult

(Bujdakova et al., 2018). Another method for modifying the surface of MMt clays involves the use of anionic surfactants (Sarier et al., 2010). These surfactants contain groups that possess a partial negative charges several research papers explain the successful intercalation of various organic anions including sulfonates (Sadek et al., 2015) and carboxylates (Rousseaux et al.,2010).

In this study, the organically modified clay was prepared by octadecyl ammonium chloride and sodium salts of adipaic and sebacic dicarboxylic acids. The PVC /organoclay nanocomposites were prepared by solution technique and the microstructure was investigated by XRD, TEM and FTIR spectroscopy. The effect of organoclay type and content on physico-mechanical and thermal properties were investigated.

\section{Experimental}

\section{Materials}

Montmorillonite Egyptian $\mathrm{Na}$ bentonite clay was supplied from south of El-Hamamm district, saved at 0.6 micron with basal plane spacing, $\mathrm{d} 001=1.26 \mathrm{~nm}$ and cation exchange capacity $(\mathrm{CEC})=120 \mathrm{meq} / 100 \mathrm{~g}$., measured according to the methods described in Refs (A M Motawie et al., 2013; 2014).

Octadecyl amine (ODA) was purchased from Sigma Aldrich, USA, Mw 269.51 gm/mole; bp 232 ${ }^{\circ} \mathrm{C}$; mp 50-52 ${ }^{\circ} \mathrm{C}$. Sebasic acid and adipic acids were supplied from CDH. Poly (vinyl chloride) PVC resin was supplied from Petrochemical Industrial Co. (Alexandria, Egypt) as a white powder made by suspension polymerization with $k$ value of 70 . Dioctyl phthalate (DOP), was supplied from North China Plastic Assistant Factory (BaoDing, China)

\section{Methods}

\section{Organoclay preparation}

Preparation of organoclay with ODACl

Organo-Na bentonite clay with ODAC was prepared by ion exchange reaction according to Refs. (Motawie et al., 2013, 2014). Na-bentonite (80 g) was dispersed into deionized water (4000ml) at 
$80^{\circ} \mathrm{C}$ for $30 \mathrm{~min}$ by a homogenizer. The prepared $\mathrm{ODACl}(30 \mathrm{~g})$ was dissolved into water $(300 \mathrm{ml})$, and the solution was added dropwise to the above $\mathrm{Na}$ - bentonite aqueous suspension under vigorous stirring for $2 \mathrm{hrs}$ to yield white precipitates. In order to ensure the complete removal of chloride ions, the precipitates were washed with deionized hot water till no precipitates of $\mathrm{AgCl}$ further formed with $\mathrm{AgNO}_{3}(0.1 \mathrm{~N})$ solution. The produced organobentonite was dried at $80^{\circ} \mathrm{C}$ under Vacuum up to a constant mass.

\section{2-Preparation of organobentonite clay with sodium salt of dicarboxylic acids:}

Sodium salt of dodecyl benzene sulfonic acid was mixed with dried sodium bentonite heated to $80{ }^{\circ} \mathrm{C}$ with stirring according to the method described in Ref. (Sarier et al., 2010). Then, the prepared sodium salt of sebacic or adipic $(1 \mathrm{mMol})$ was added to the obtained colloidal dispersion, with stirring at $80^{\circ} \mathrm{C}$ for $2 \mathrm{hrs}$.Finally, the free surfactants were removed by centrifugations and washing cycles.

\section{3-PVC nanocomposites preparation}

Different organoclay loadings(i.e. 1,2,3,4,5and $6 \mathrm{wt} \%$ ) were dispersed in PVC solution( $1 \mathrm{~g}$ in $5 \mathrm{ml}$ THF) in presence of DOP plasticizer $(0.5 \mathrm{~g})$ using a high speed mixing machine (IKA Labortechnik Staufen, Germany) at $300 \mathrm{rpm}$ for $60 \mathrm{~min}$., The solution was further mixed in ultrasonic bath machine (power sonic Ltd. Vrable, Slovakia). The formulated solutions were poured on petri dishes to evaporate the solvent by the following steps : air drying at room temperature for $72 \mathrm{~h}$, vacuum drying at $40{ }^{\circ} \mathrm{C}$ for $48 \mathrm{~h}$, and finally at $70^{\circ} \mathrm{C}$, for $3 \mathrm{~h}$. In an electrically heated hydraulic press( Carver laboratory press Model M AerNo.11086-692 made in U.S. Aloy WABASH,IN46992) the samples were molded at $170^{\circ} \mathrm{C}$ and a pressure $15 \mathrm{MPa}$ for $2 \mathrm{~min}$ followed by cooling on room temperature $\left(25^{\circ} \mathrm{C}\right)$ ( Thabet and Ebnalwaled, 2017).

\section{Measurements:}

X-ray diffraction (XRD) measurements were performed on a Philip's X-ray diffractometer PW1390 with Ni-filtered $\mathrm{Cu} \mathrm{K} \alpha$ radiation at generator voltage of $40 \mathrm{kV}$, wavelength of 0.154 $\mathrm{nm}$ at room temperature $\left(25^{\circ} \mathrm{C}\right)$. The diffraction angle, $2 \Theta$, was scanned at a rate of $2 \mathrm{~min}$.

Transmission electron microscopy (TEM) micrographs were taken using a JEOL JX 1230 TEM with microanalyzer electron probe.

FTIR spectra of samples were obtained using a Jascow FTIR 430 series infrared spectrophotometer equipped with $\mathrm{KBr}$ discs.

The physico-mechanical Properties (i.e. tensile strength, Young's modulus and elongation at break) were measured using a universal testing machine (tension compression to $5 \mathrm{kN}$; product name: H5K-S UTM; manufactured by Tinuis Olsen (UK)). The compressed sheets were cut into dumbbell-shaped specimens with appropriate punching dies with width of 4mm (DIN 53504 STABIN$^{\wedge} \mathrm{EF}$ ). The specimens with width $4 \mathrm{~mm}$, a neck length of $50 \mathrm{~mm}$, a thickness of 1-1.5 $\mathrm{mm}$, were tested at a crosshead speed of $50 \mathrm{~mm} / \mathrm{min}$ as per ASTM D638. Thermogravimetric analysis (TGA) was carried out using a (Thermogravimetric Analyzer; product name: TGA-50; manufactured by SHIMADZU CORPORATION (Japan)). The heating rate was carried out at 
$10^{\circ} \mathrm{C} / \mathrm{min}$ under nitrogen gas atmosphere from $20^{\circ} \mathrm{C}$ to $800^{\circ} \mathrm{C}$. The reported results were averaged from a minimum of five specimens.

\section{Result and discussion}

\section{$\mathrm{X}$-ray diffraction analysis $(\mathrm{XRD})$ :}

XRD patterns for Na-bentonite clay, organoclay with the prepared modifiers and PVC nanocomposites are shown in Figs1\&2 and data are tabulated in Table.1

Na- bentonite clay, (Fig.1(a)), exhibits its characteristic diffraction peak at approximately $6.9^{\circ}$, which corresponds to basal spacing of $1.4 \mathrm{~nm}$ according to Bragg's equation, that appears in case of intermolecular water inside the structures of the clays. With organophilic modification with ODACl, (Fig.1b) there are two peaks of bentonite at $4.73^{\circ}$ and $2.28^{\circ}$ corresponding to the interlayer spacing of the 1.86 and $3.861 \mathrm{~nm}$. The higher basal spacing compared with the value of sodium bentonite is caused by intercalation of organic compound (ODACl) into interlayer spaces of $\mathrm{Na}$ bentonite. For PVC/clay-ODA (3wt \%) Fig.1(c), the regular structures of intercalated clay are disappearing, the clays are supposed to be more exfoliated and disordered in PVC matrix. For carboxylated clay, it was found that basal spacing of clay modified with $\mathrm{Na}$ sebacate Figure 2(a) was greater than treated by $\mathrm{Na}$ adipate Figure2 (b) in comparison to that with ODACl as listed in Table 1.

The interlayer spacing of clay was obviously increased after the treatment with the carboxylate salt. This reveals that the long anion carboxylate had intercalated into the interlayer of clay. PVC/ sebacate carboxylated clay (3wt \%) nanocomposites, Figure (2c), have no diffraction peak appearing at the testing scale, indicating that PVC chains had intercalated into the galleries and expanded the layers of clay. As a result, an exfoliated PVC/ sebacate carboxylated clay nanocomposites were produced. In this case, the dipole- dipole interaction between PVC chains with strong polarity and polar silicate layers surface may act as a driving force for PVC chains to intercalate into silicate layers.

Table 1: XRD for Na-bentonite and the prepared organoclays

\begin{tabular}{|l|l|l|}
\hline Sample & $\mathbf{2 ~} \mathbf{d -}$ space \\
\hline Na-bentonite & 6.9 & 1.4 \\
\hline ODA/clay & $4.73,2.28$ & $1.86,3.861$ \\
\hline Adipate/clay & 5.53 & 1.604 \\
\hline Sebacate/clay & $4.6,2.3$ & $1.925,3.85$ \\
\hline
\end{tabular}




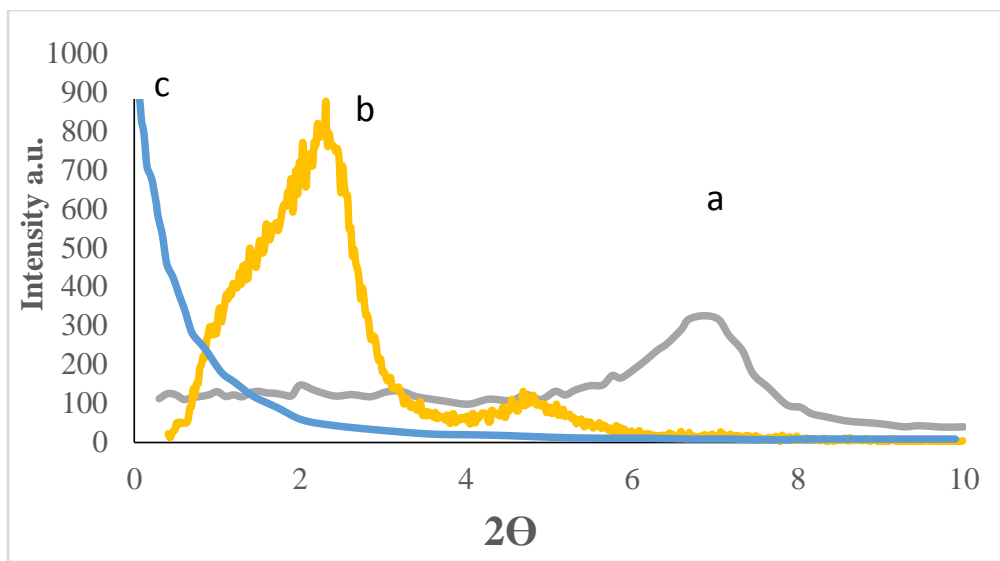

Fig.1: XRD of Na-bentonite (a), ODA/clay (b) and PVC/ ODA- clay (3wt \%) (c)

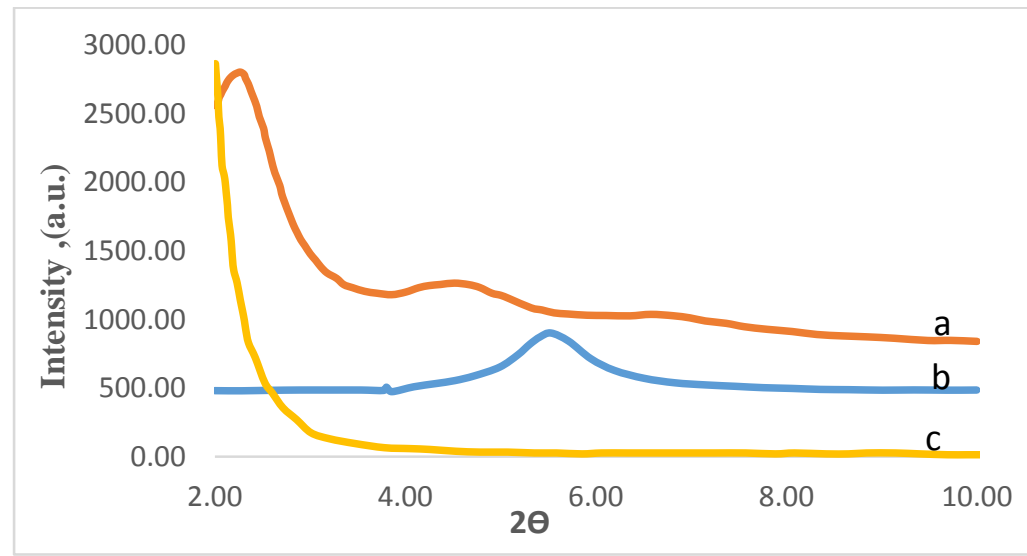

Fig.2: XRD of Na-sebacate-clay (a), Na-adipate- clay (b) and PVC/Na-sebacate-clay (3 wt\%) (c)

\section{Transmission electron microscopy ( TEM)}

Figure 3 shows TEM images of Na-bentonite clay, the prepared organoclay and PVC/ nanocomposites. TEM picture of Na-bentonite 3(a), exhibits as expected large clay aggregates of several microns. While the dark areas were the stacks of organolayers of clay after intercalation of $\mathrm{ODACl}$ and enlarging the interlayer spacing of Na-clay Fig.3 (b). Also, on using Nacarboxylates, we show that orientation of bentonite clay layers occurred and they are arranged in order structure, which indicates that sodium carboxylate formed an intercalation structure with the used clay Fig.3(c,d) for $\mathrm{Na}$ adipate and $\mathrm{Na}$ sebacate, respectively. While for the prepared nanocomposites with $3 \mathrm{wt} \%$ of the used modifier (ODA-clay and Na-sebacate clay) the gray areas were PVC matrix, and long gray lines were exfoliated organoclay layers Fig.3 (e,f). Thus, TEM results demonstrated that many silicate layers are exfoliated into nanometer layers. This is in agreement with the XRD results. On the other hand, on using $6 \mathrm{wt} \%$ content of sebacate clay in PVC, Figure 3(g), the nanocomposite displayed worse dispersion of this carboxylated clay in the 
PVC matrix, which may be mainly attributed to aggregation formation of sebacate clay in PVC matrix.
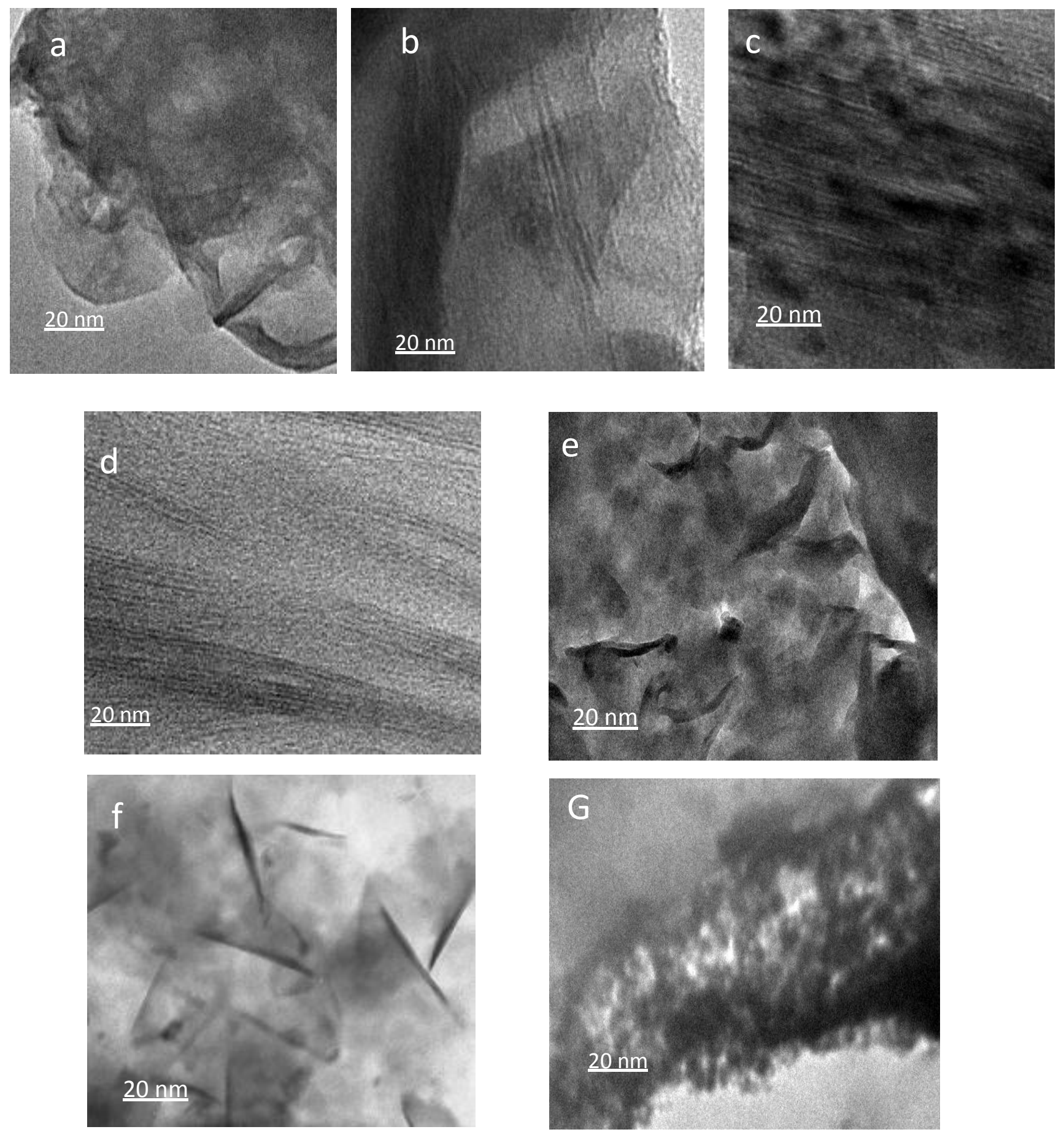

Fig. 3: TEM of Na- bentonite clay (a), ODA-clay (b) Na- adipate-clay (c), Na- sebacate- clay(d) and PVC/ODA-clay (3wt\%) (e), PVC/ Na-sebacate-clay (3wt\%) (f) and PVC/Na-sebacate-clay $(6 \mathrm{wt} \%)(\mathrm{g})$ nanocomposites. 


\section{Fourier transform infrared measurements (FTIR)}

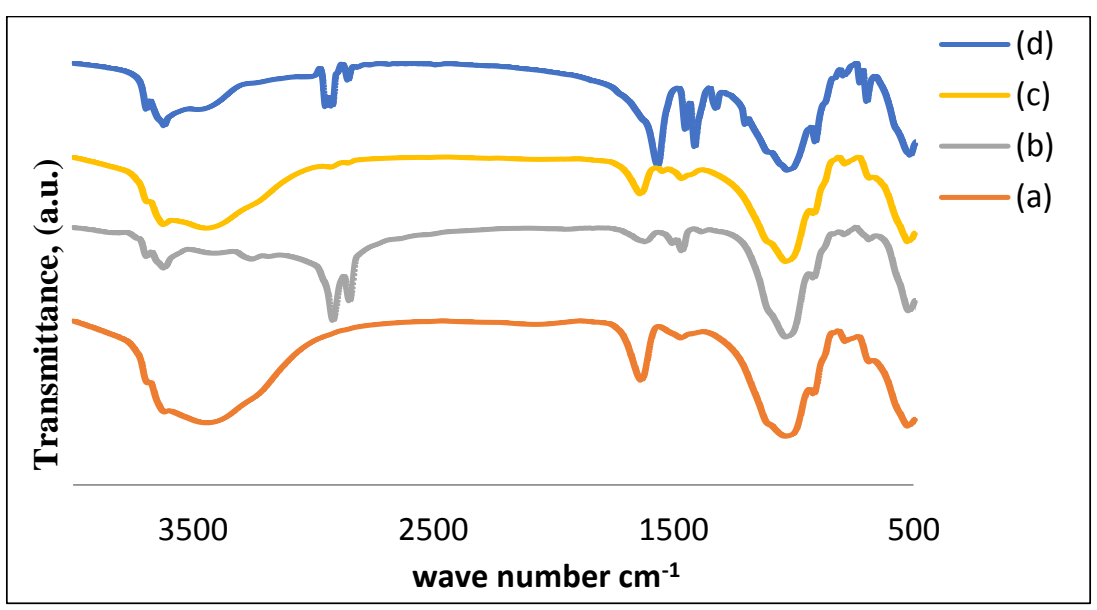

Fig.4: FTIR of Na bentonite (a), organoclay with ODA (b) organoclay with Na- adipate (c), organoclay with Na- sebacate(d)

FTIR spectra for Na-bentonite clay and the prepared organoclay are illustrated in Fig 4 in the range of 4000-500 $\mathrm{cm}^{-1}$. The Infrared spectrum of unmodified clay Fig 4 a presents the following peaks the asymmetric stretching vibration of the structural $-\mathrm{OH}$ group at $3614 \mathrm{~cm}^{-1}$, the symmetric stretching vibration of hydroxyl group at $3407 \mathrm{~cm}^{-1}$, the bending in plane vibration of $\mathrm{H}-\mathrm{O}-\mathrm{H}$ at $1635 \mathrm{~cm}^{-1}$. An organic modifier Fig.4 (b-d) indicates the presents of vibrational bands of organic modifier. The organoclay presents three peaks in the FTIR spectrum. Bands at 2923and $2854 \mathrm{~cm}^{-1}$ are attributed to $\mathrm{C}-\mathrm{H}$ asymmetric and symmetric stretching vibrations. The band at $1467 \mathrm{~cm}^{-1}$ is assigned to the $\mathrm{C}-\mathrm{H}$ bending vibration of the used modifier(Sadek and ElNashar, 2012). The stretching band of the $\mathrm{OH}$ groups at 3614 of pure $\mathrm{Na}$ bentonite, shifted to 3621 and $3619 \mathrm{~cm}^{-1}$ in organoclay samples modified with adipate, sebacate salts respectively. This shift towards the higher wave numbers implies the removal of some structural hydroxyl groups from the $\mathrm{Si}-\mathrm{OH}$ and $\mathrm{Al}-\mathrm{OH}$ sites and some $\mathrm{H}_{2} \mathrm{O}$ was removed from the galleries when the carboxylate acid salts entered. Similarly, the bending -in-plane vibrations of the $\mathrm{OH}$ groups are characterized by a broad band at $1635 \mathrm{~cm}^{-1}$ This band shifted slightly to a lower wave numbers of $1626 \mathrm{~cm}^{-1}$ in the FTIR spectra of the modified samples. The broad band observed at $3407 \mathrm{~cm}^{-1}$ corresponds to the overlapping stretching vibrations of both the structural and free $\mathrm{OH}$ groups. This band shifted to 3455,3442 and $\mathrm{cm}^{-1}$ for organoclay with Na-sebacate and Na-adipate, respectively. While on using ODA this band shifted to $3612 \mathrm{~cm}-1$ with lower intensity. This indicates that all the modifiers ions were incorporated within the galleries of the bentonites. The bands at 1565,970 and $1561,914 \mathrm{~cm}^{-1}$ in the carboxylated clay assigned to the asymmetric stretching vibrations of the carboxyl groups of sebacate and adipate slats, respectively. This indicates that, the existence of sebacate and adipate anions as intercalates and as adsorbents on the clay layers. The peaks at 1027 and $919 \mathrm{~cm}^{-1}$ belonging to the stretching and bending vibertions of the tetrahedral and octahedral silica -alummina layers of ( $\mathrm{Si}-\mathrm{O}$ and $\mathrm{Al}-\mathrm{O}$ ) of $\mathrm{Na}$ bentonite, shifted to the lower wave numbers (i.e. 1010- 1007 and $912-910 \mathrm{~cm}^{-1}$, respectively. These shifts to lower wave number due to the attractions between $\mathrm{Si}-\mathrm{O}$ or $\mathrm{Al}-\mathrm{O}$ groups and carboxylate ions. Thus, FTIR was an evidence for the structural changes of the clay from hydrophilic to hydrophobic character. 


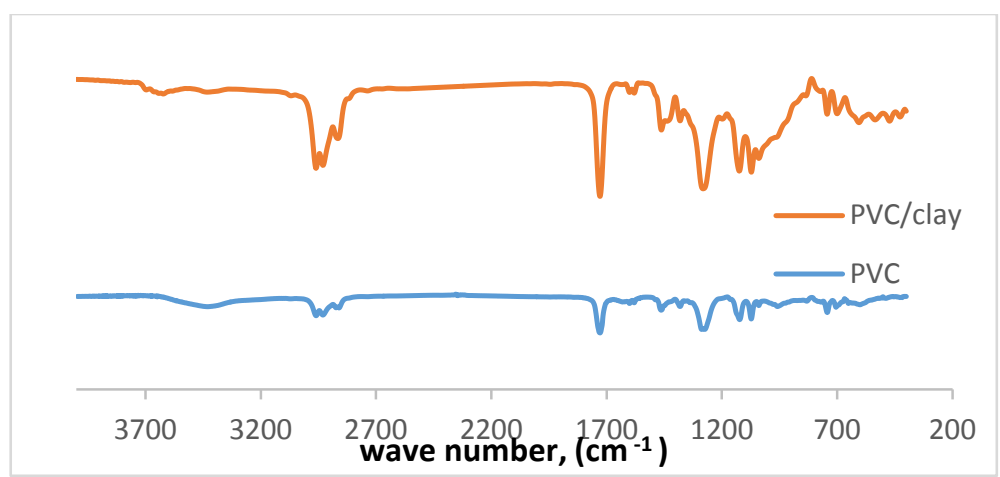

Fig. 5: FTIR of PVC and PVC/Na-sebacate organoclay nancomposite

Fig.5 shows the FTIR of PVC/Na-sebacate nanocomposite as compared with unfilled PVC, the spectra are rather similar to unfilled PVC. This result as already shown in an earlier paper (Karakehya and Bilgiç, 2014).

\section{Mechanical properties}

Figure 6 shows the variation of mechanical properties (i.e tensile strength, Young's modulus and elongation at break) as a function of the modifier clay type and loading at constant DOP content for PVC- clay nanocomposites. It is clear that the introduction of a small amount of modified clay led to a slight increase in the tensile strength and Young's modulus of the nanocomposites in comparison to pure PVC. Also, increasing the modified clay content up to $3 \mathrm{wt} \%$, the tensile strength and Young's modulus of the nanocomposites were increased up to maximum values Fig. $6(a, b)$. These observation are expected owing to the reinforcing effect of the used modified clays and entanglement of PVC chains, with increasing k-value equal to 70. Also, because of exfoliation of modified clay in polymer chains, which has already discussed in this text. Similar results have already been reported in the literature, indicating the stiffening effect of different types of nanoclay (Esmizadeh et al., 2014; Shimpi and Mishra, 2010). When the modified clay content was more than $3 \%$ and up to $6 \%$, the tensile strength and Young's modulus decrease because of the agglomeration of clay particles, which is a problem that has a major significance for polymer nanocomposites, in general. Also, for the elongation at break measurement (Fig.6 c), it was found that the addition of a small amount of clay, $3 \mathrm{wt} \%$, to virgin PVC cause a slightly increase in elongation at break, since the well dispersed silicate acted as plasticizers to decrease the $\mathrm{T}_{\mathrm{g}}$ of the nanocomposites. While increasing the clay content, the elongation percentages decreases. The reason for this competitive result is that the link of PVC chains to clay plates increased the $\mathrm{T}_{\mathrm{g}}$ of the PVC nanocomposites leading to a decrease in elongation percentages. This was in agreement to Refs (Mingling and Demin, 2008; Wang et al., 2001). With respect to clay modifier type, the carboxylated clay possess stronger polarity than DOA-pretreated clay, which could enhance the interfacial interaction between the layered silicates and PVC matrix. This may be the reason for the difference in the mechanical properties of these two types of PVC/clay nanocomposites. Thus, one can conclude that nanocomposites with sebacate clay exhibited an enhancement in tensile strength, Young's modulus and elongation percentage as compared with adipate clay and ODA clay at the same content (3wt\%).Accelerated decomposition of PVC/ODA-clay compositions in the initial stage compared with 
$\mathrm{PVC} /$ carboxylate clay, as will be seen later, is responsible for lower mechanical properties of the former. The carboxylated acid salts possess stronger polarity than octadecylamine which could enhance the interfacial interaction between the layered silicate and PVC matrix. This may be the reason for the difference in the mechanical properties of these two types of $\mathrm{PVC} /$ bentonite nanocomposite.
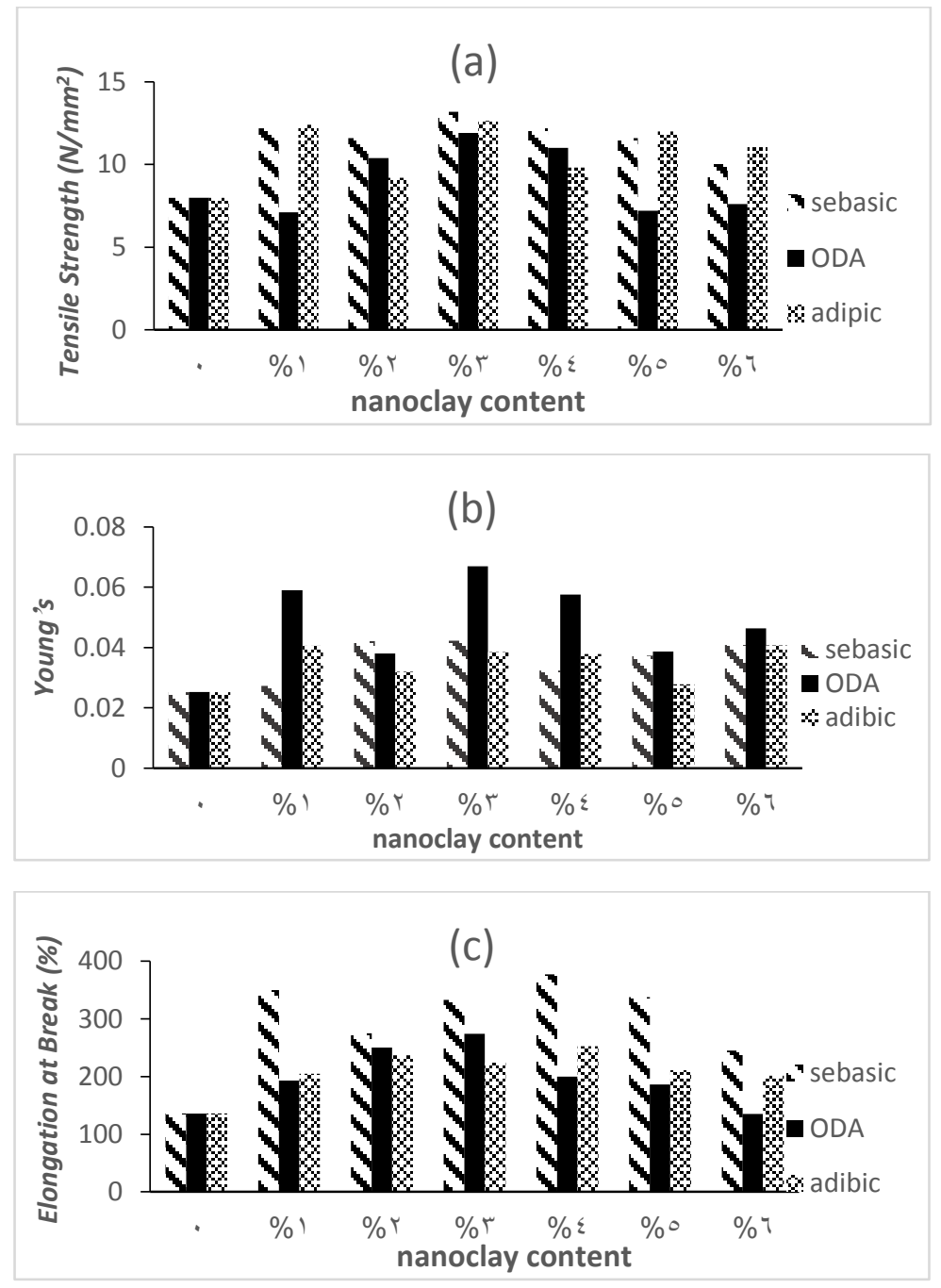

Fig. 6: Mechanical properties of PVC and PVC nanocomposites (a) the tensile strength, (b) Young's modulus and(c) elongation at break.

\section{Thermogravimetric analysis (TGA)}

\section{TAG results of the prepared organoclay samples}

Thermal decomposition of Na-bentonite and modified bentonite with the prepared modifiers is shown in Figure 7.

Two thermal degradation transitions (i.e. $\mathrm{T}_{\mathrm{H} 2 \mathrm{O}}$ and $\left.\mathrm{T}_{\mathrm{OH}}\right)$ were observed for Na-bentonite. $\left(\mathrm{T}_{\mathrm{H} 2 \mathrm{O}}\right)$ (up to $110^{\circ} \mathrm{C}$ ) and is attributed to the volatilization of both free water and water inside the 
interlayers space. $\mathrm{T}_{\mathrm{OH}}$ (up to $700^{\circ} \mathrm{C}$ ) and attributed to the loss of structural water resulting from clay dehydroxylation or dehydration(Leite et al., 2010).

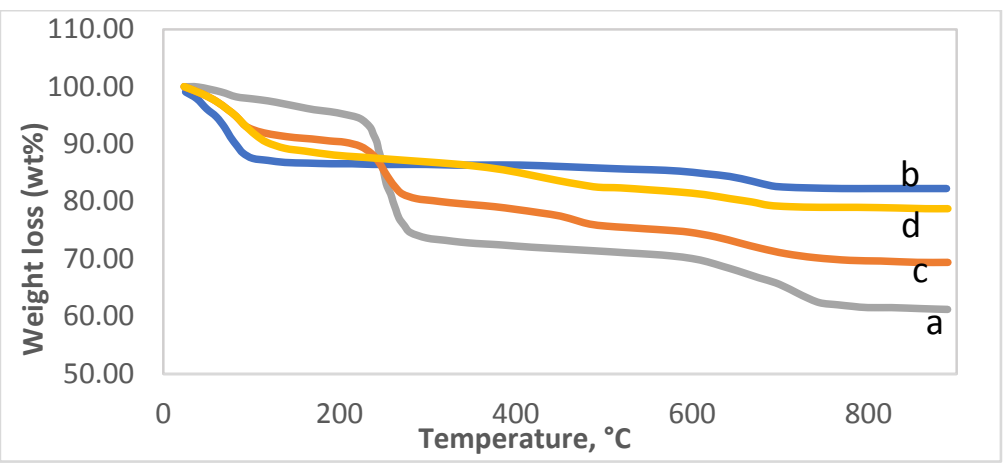

Fig. 7: TGA of Na bentonite (a), organoclay with ODA (b) organoclay with Na- adipate (c), organoclay with $\mathrm{Na}-$ sebacate(d)

Modified bentonite with ODA cation showed onset and maximum decomposition temperatures $\left(186^{\circ} \mathrm{C}\right.$ and $275^{\circ} \mathrm{C}$, respectively). This means that this type of organoclays displays a lower dehydration temperature than unmodified clay. For bentonite clay modified with $\mathrm{Na}$ salts of adipic or sebacic acid. Figure 7 shows the thermal degradation of the $-\mathrm{CH}_{2}$ and carboxyl groups at about $200-350^{\circ} \mathrm{C}$. The thermal degradation between $600-700^{\circ} \mathrm{C}$ is attributed to the dehydroxylation of the remaining $\mathrm{OH}$ groups of $\mathrm{Na}$ - bentonite. Also, may be attributed to the organic degradation of carboxylate anion intercalates. These findings verify the successful formation of organophilic structure with intercalated morphology of the modifiers into the silicate layers as seen before in TEM images, Fig 3 (b-d). And the replacement of the carboxylate anions by the $\mathrm{OH}$ groups of the tetrahedral $\left(\mathrm{Si}^{4+}\right)$ and octahedral $\left(\mathrm{Al}^{3+}\right)$ layers as confirmed before by FTIR analysis. Thus, carboxylated acid salts modified bentonite seem to be suited for the preparation of polymer nanocomposites with better thermal stability.

\section{TGA results of the prepared nanocomposites}
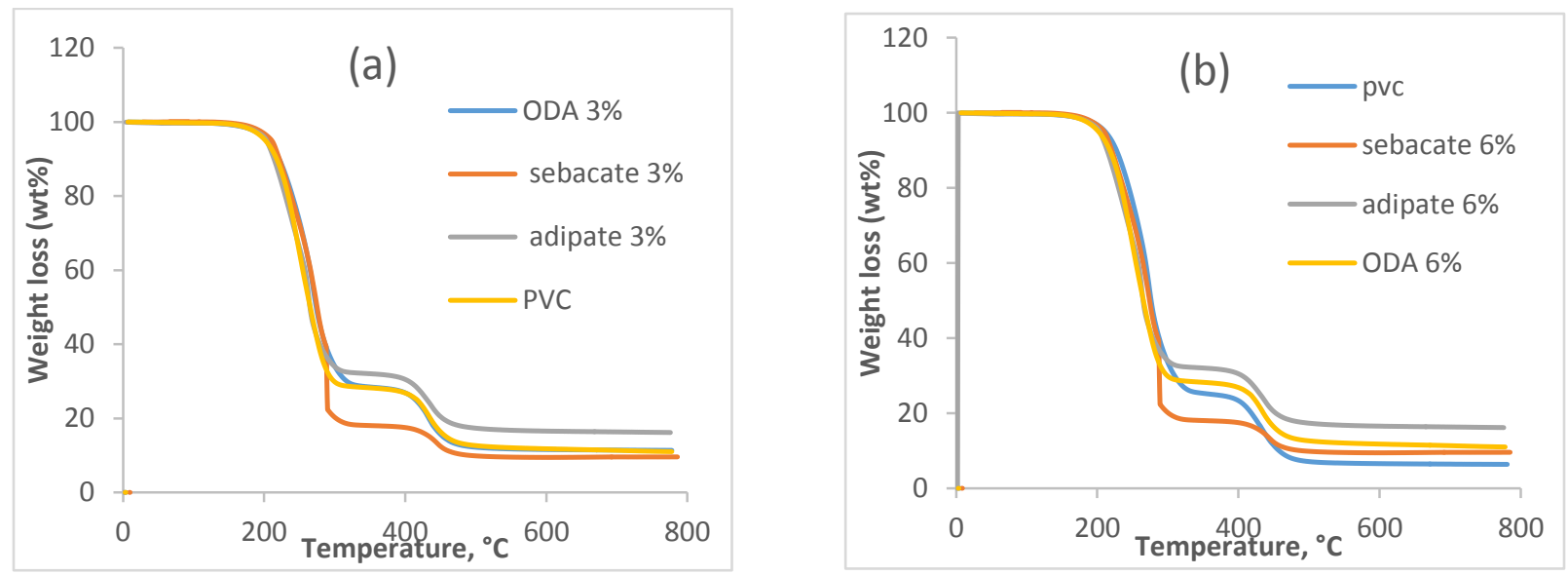

Fig. 8: TGA curves of PVC with PVC nanocomposites 3 wt. \% (a) and PVC with PVC nanocomposites 6 wt. \% (b). 
Table 2: TGA results of PVC and PVC nanocomposites at $3 \mathrm{wt} \%$ and $6 \mathrm{wt} \%$

\begin{tabular}{|c|c|c|c|c|c|c|c|}
\hline \multirow{2}{*}{ Sample } & \multicolumn{3}{|c|}{$11^{\text {st }}$ stage } & \multicolumn{3}{c|}{$2^{\underline{\text { nd }}}$ stage } & \multirow{2}{*}{$\begin{array}{c}\text { Residual \% } \\
\text { At 800 }\end{array}$} \\
\cline { 2 - 8 } & $\mathrm{T}_{\text {onset }}$ & $\mathrm{T}_{\mathrm{fd}}$ & Mass loss\% & $\mathrm{T}_{\text {onset }}$ & $\mathrm{T}_{\mathrm{fd}}$ & Mass loss\% & \\
\hline PVC & 199 & 267 & 74 & 406 & 440 & 20 & 6 \\
\hline PVC/ ODA 3\% & 182 & 265 & 75.5 & 400 & 464 & 13 & 11.5 \\
\hline PVC/ ODA 6\% & 183 & 302 & 75 & 399 & 477 & 14 & 11 \\
\hline PVC/Adipate 3\% & 180 & 306 & 71 & 395 & 480 & 12.5 & 16.5 \\
\hline PVC/Adipate 6\% & 187 & 333 & 75 & 399 & 473 & 14.6 & 10.7 \\
\hline PVC/sebacate 3\% & 186 & 300 & 71.5 & 412 & 476 & 12 & 16.5 \\
\hline PVC/sebacate6\% & 177 & 311 & 72 & 414 & 473 & 15.6 & 12.4 \\
\hline
\end{tabular}

Figs 8 (a, b) show TGA for the unfilled PVC and PVC nanocomposites with the prepared modified clay. The TGA results are summarized in Table2 reflecting two stages of decomposition the first stage of decomposition maybe attributed to PVC degradation, which comprises a sequential loss of hydrogen chloride with the formation of polyene sequences (Awad et al., 2009). The temperature of onset decomposition ( $\mathrm{T}_{\text {onset }}$ ) of $\mathrm{PVC}$ is $199^{\circ} \mathrm{C}$ with a maximum decomposition temperature $(\mathrm{T} \max )$ at $267^{\circ} \mathrm{C}$ and presents a significant mass loss at $74 \%$. Between $267^{\circ} \mathrm{C}$ and $406^{\circ} \mathrm{C}$, the sample becomes thermally stable, does not lose weight in this temperature range, forming polyacetylene with conjugated double bonds more stable than PVC (Yang et al., 2006). From $406^{\circ} \mathrm{C}$ and up to $440^{\circ} \mathrm{C}$, a second decomposition stage was loss of $20 \mathrm{wt} \%$. Above $440^{\circ} \mathrm{C}$ and up to $800^{\circ} \mathrm{C}$, residue of $6 \mathrm{wt} \%$ was formed. For the PVC nanocomposites with clay-ODA, in the first stage, it was found that the dehydrochlorination temperature of PVC matrix decreased with a higher mass loss as compared with unfilled PVC. This is related to that, the organic quaternary ammonium salt is easy to thermally decompose following Hofmann elimination, leaving acidic proton on the silicate surface (Leite et al., 2010). This acidic site $\left(\mathrm{H}^{+}\right)$on the surface of clay have catalytic effect during the initial stage of PVC decomposition (Awad et al., 2009; Yang et al., 2006)Also, there is a strong interaction between the chloride in PVC and the quaternary ammonium cation ions in orgnoclay. Thereby, the ODA/clay acts as a catalyst to enhance the dehydrochlorination of the PVC matrix. In contrast to carboxylate pretreated clay which delay the dehydrogenation temperature of PVC matrix reflecting an increased in the temperature with an increase in the residual weight at $800^{\circ} \mathrm{C}$ in comparison to ODA pretreated clay as listed in Table2. However, in the second stage, the thermal decomposition temperature of the dehydrochlorinated $\mathrm{PVC}$ and char at $800^{\circ} \mathrm{C}$ are slightly increased in the presence of silicate layers. This can be attributed to the fact that exfoliated silicate layers can act as a physical barrier to minimize the transport of the volatile products out of the composite during the thermal decomposition of the dehydrochlorinated product out of the composite. A behavior that has been shown to relate directly to the dispersion filler in a polymer matrix (A.M. Motawie et al., 2014). Thus, one can conclude that 6 wt $\%$ of organoclay destabilize the phase morphology with aggregation formation of organoclay. This indicates degradation at a lower temperature with lower residue with respect to ODA at $3 \mathrm{wt} \%$. This is also true, for the adipate and sebacate clay which maximize the dehydrochorinated 
temperature of PVC matrix and char at $800^{\circ} \mathrm{C}$ in comparison to ODA pretreated clay. Also, as expected adipate pretreated clay exhibits better thermal stability than sebacate one.

\section{Differential thermogravimetric analysis (DTGA):}
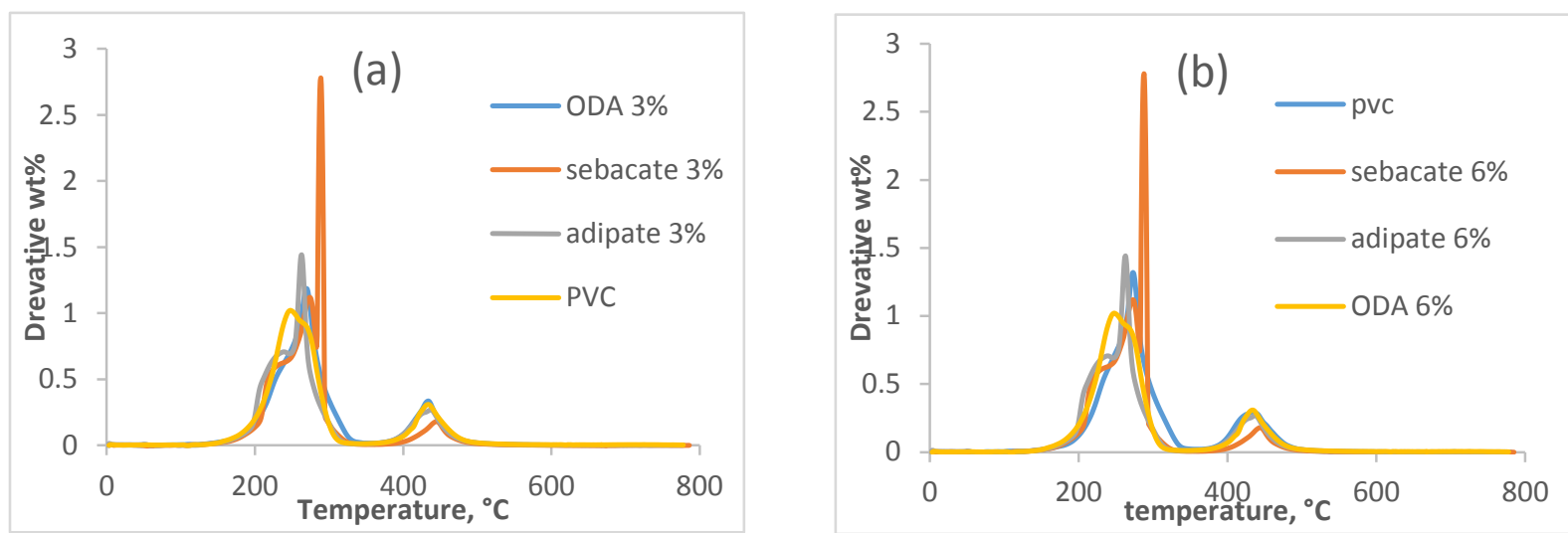

Fig. 9: DTG curves of PVC with PVC nanocomposites 3 wt. \% (a) and PVC with PVC nanocomposites 6 wt. \% (b).

Table 3: DTG of o PVC and PVC nanocomposites at 3wt $\%$ and $6 \mathrm{wt} \%$

\begin{tabular}{|c|c|c|}
\hline Sample & $\mathbf{T}_{\max 1}$ & $\mathbf{T}_{\max }$ \\
\hline PVC & 270 & 433 \\
\hline PVC/ ODA 3\% & 252 & 439 \\
\hline PVC/ ODA 6\% & 252 & 438 \\
\hline PVC/Adipate 3\% & 271 & 443 \\
\hline PVC/Adipate 6\% & 267 & 434 \\
\hline PVC/sebacate 3\% & 271 & 442 \\
\hline PVC/sebacate6\% & 265 & 440 \\
\hline
\end{tabular}

As expected from the above mentioned results in TGA section, there are two maximum mass loss temperatures $\left(\mathrm{T}_{\max 1}\right.$ and $\left.\mathrm{T}_{\max 2}\right)$ as the peaks in the differential thermogravimetric analysis (DTGA), listed in Table 3 and shown in Figures 9 (a,b). Thus, from TGA: $T_{\max 1}$ are decreased while $\mathrm{T}_{\max 2}$ are increased in presence of silicate layers. While for carboxylated salts treated clay, $\mathrm{T}_{\max 1}$ are slightly increased with a sharp increase in $\mathrm{T}_{\max 2}$ in comparison to ODA pretreated clay. This indicates higher thermal stability of carboxylated acid salts nanocomposites. Again, the table illustrate the sharp decrease in both $\mathrm{T}_{\max 1}$ and $\mathrm{T}_{\max 2}$ on using $6 \mathrm{wt} \%$ of modified clay as explained before in TGA section.

\section{Conclusions}

Based on the results obtained in this study, we can conclude the following conclusions:

PVC nanocomposites were synthesized by solution process in presence of different organoclay types and have been studied varying the organoclay type and loading up to $6 \mathrm{wt} \%$.

X-ray diffraction studies have proved the formation of exfoliated nanocomposites. 
FTIR data of the composites did not show any remarkable change due to the addition of the modified clay in PVC.

The mechanical properties of the nanocomposites showed improvement for the compound $\mathrm{PVC} /$ carboxylated clay compared to PVC composites containing ODA, at the same loading.

Organic amine can catalyze PVC degradation but carboxlated acid salts have less effect on PVC nanocomposites degradation.

It is worthy to notice that, PVC containing dicarboxylic acid salts (3 wt $\%$ ) led to simultaneous improvement in the mechanical properties and thermal stability of nanocomposite formed. This allows processing without degradation of polymer as is often observed for the more common ammonium ion based modifiers.

\section{References:}

Awad WH, Beyer G, Benderly D, Ijdo WL, Songtipya P, Jimenez-gasco M, et al. Material properties of nanoclay PVC composites. Polymer 2009;50:1857- 1867.

Bakar NA, Chee CY, Abdullah LC, Ratnam CT, Ibrahim NA. Thermal and dynamic mechanical properties of grafted kenaf filled poly (vinyl chloride)/ethylene vinyl acetate composites. Mater Des 2015;65:204-211.

Bujdáková H, Bujdáková V, Májeková-KoščováH, B. Gaálováa, B, V. Bizovskác, V, P. Boháčc, P, Bujdák J, Antimicrobial activity of organoclays based on quaternary alkylammonium and alkylphosphonium surfactants and montmorillonite.Appl Clay Sci 2018;158:21-28

Cui Y, Kumar S, Kona R, Houcke D Van. Gas barrier properties of polymer / clay nanocomposites. RSC Adv 2015;5:63669-63690.

Deka BK, Maji TK, Mandal M. Study on properties of nanocomposites based on HDPE ,LDPE, PP, PVC, wood and clay. Polym Bull 2011:1875-1892.

Esmizadeh E, Moghri M, Saeb MR, Nia MM, Nobakht N, Bende NP. Application of Taguchi Approach in Describing the Mechanical Properties and Thermal Decomposition Behavior of Poly ( vinyl chloride )/ Clay Nanocomposites: Highlighting the Role of Organic Modifier. J VINYL Addit Technol 2014:1-9.

Guo F, Aryana S, Han Y, Jiao Y. A Review of the Synthesis and Applications of PolymerNanoclay Composites. Appl Sci 2018;8:1696.

Istrate OM, Chen B. Applied Clay Science Structure and properties of clay / recycled plastic composites. Appl Clay Sci 2018;156:144-151.

Karakehya N, Bilgiç C. International Journal of Adhesion \& Adhesives Surface characterisation of montmorillonite / PVC nanocomposites by inverse gas chromatography. Int J Adhes Adhes 2014;51:140-147.

Leite IF, Soares APS, Carvalho LH, Raposo CMO, Malta OML, Silva SML. Characterization of pristine and purified organobentonites. J Therm Anal Calorim 2010;100:563-569.

Liu C, Luo YF, Jia ZX, Zhong BC, Li SQ, Guo BC, et al. Enhancement of mechanical properties 
of poly ( vinyl chloride ) with polymethyl methacrylate-grafted halloysite nanotube. EXPRESS Polym Lett 2011;5:591-603.

Liu F, Liu H, Li X, Zhao H, Zhu D, Zheng Y, et al. Nano-TiO2@Ag/PVC film with enhanced antibacterial activities and photocatalytic properties. Appl Surf Sci 2012;258:4667-4671.

Mansour NA, Sadek EM, Elkomy GM, Shara SI, Motawie AM. Some Studies on Poly (vinyl chloride) /carbon Nanocomposites. Int J Pure Appl Chem 2011;6:409-414.

Mingliang G, Demin J. Influence of Organoclay Prepared by Solid State Method on the Morphology and Properties of Polyvinyl Chloride/Organoclay Nanocomposites. ELASTOMERS Plast 2008;40: 223-235.

Moghri M, Dragoi EN, Salehabadi A, Shukla, Devesh Kumar Vasseghian Y. Effect of various formulation ingredients on thermal characteristics of PVC / clay nanocomposite foams: experimental and modeling. E-Polymers 2017;17:119-128.

Moghri M, Khakpour M, Akbarian M, Saeb MR. Employing Response Surface Approach for Optimization of Fusion Characteristics in Rigid Foam PVC / Clay Nanocomposites. J VINYL Addit Technol 2015.

Motawie AM, Badr MM, Abo-El-Yazid, DE, and El Komy, DA. Egyptian Patent no. 26250/2013.Treatment of Egyptian Bentonite to Modified Nano Egyptian.

Motawie AM, Khalil AA, Eid AIA, El-Ashry KM, Sadek EM. Some Studies on Poly (vinyl chloride)/Layered Silicate Nanocomposites Part 1, Morphology, Physico-mechanical, and Thermal Properties. J Appl Sci Res 2014;9:6355-6364.

Motawie AM, Madani M, Esmail EA, Dacrorry AZ, Othman HM, Badr MM, et al. Electrophysical characteristics of polyurethane / organo-bentonite nanocomposites. Egypt J Pet 2014;23:379-387.

Motawie MA, Ahmed NM, Elmesallamy SM, Sadek EM, Kandile NG. Unsaturated Polyesters / Layered Silicate Nanocomposites: Synthesis and Characterization. IOSR J Appl Chem 2014;7:34-43.

Motawiea AM, Mohamed MZ, Ahmed SM, El-Komy D, Badawy NA, Abd El All AY, et al. Synthesis and Characterization of Modified Novolac Phenolic Resin Nanocomposites as Metal Coatings 1. Russ J Appl Chem 2015;88:970-976.

Rousseaux DDJ, Sclavons M, Godard P, Marchand-Brynaert J. Carboxylate clays: A model study for polypropylene/clay nanocomposites. Polym Degrad Stab 2010;95:1194-1204.

Sadek EM, El-Nashar DE. Preparation and characterization of nitrile butadiene rubber-nanoclay composites with maleic acid anhydride as compatibilizer. Part I: Rheometric and swelling characteristics. High Perform Polym 2012;24:654-663.

Sadek EM, El-nashar DE, Ahmed SM. Influence of modifying agents of organoclay on the properties of nanocomposites based on acrylonitrile butadiene rubber. Egypt $\mathrm{J}$ Pet 2018;27:1177-1185.

Sadek EM, El-Nashar DE, Ahmed SM. Effect of Organoclay Reinforcement on the Curing 
Characteristics and Technological Properties of Styrene - Butadiene Rubber. Polym Compos 2015.

Sadek EM, Khalil AA, Fatthallah NA, Eid AIA, Motawie AM. Some Studies on Poly ( vinyl chloride )/ Layered Silicate Nanocomposites: Electrical, Antibacterial and Oxygen Barrier Properties. IOSR J Appl Chem 2014;7:37-45.

Sarier N, Onder E, Ersoy S. The modification of Na-montmorillonite by salts of fatty acids : An easy intercalation process. Colloids Surfaces A Physicochem Eng Asp 2010;371:40-49.

Shimpi NG, Mishra S. Studies on Effect of Improved d -Spacing of Montomorillonite on Properties of Poly ( vinyl chloride ) Nanocomposites. J Appl Polym Sci 2010;119:148-154.

Sterky K, Jacobsen H, Jakubowicz I, Yarahmadi N, Hjertberg T. Influence of processing technique on morphology and mechanical properties of PVC nanocomposites. Eur Polym J 2010;46:1203-1209.

Thabet A, Ebnalwaled A, Improvement of surface energy properties of PVC nanocomposites for enhancing electrical applications, Measurement 2017;110: 78-83

Wang D, Paiuow D, Yao Q, Wilkie CA. PVC-Clay Nanocomposites: Preparation, Thermal and Mechanical Properties. J VINYL Addit Technol 2001;7(4):203-213.

Weiss Z, Kalendova A, Gerard J-F, Malac J, Simonik J,Kovarova L. Sturcture analysis of PVC nanocomposites. MacromolSymp 2005;211:105-114.

Yang D-Y, Liu Q-X, Xie X-L, Zeng F-D. Sturcture and thermal properties of exfoliated PVC / layered silicate nanocomposites via in situ polymerization. J Therm Anal Calorim 2006;84:355359.

Zhu TT, Zhou CH, Kabwe FB, Wu QQ, Li CS, Zhang JR. Exfoliation of montmorillonite and related properties of clay/polymer nanocomposites. Appl Clay Sci 2019 


\section{الملخص باللغة العربية}

تحضير متراكبات بولي ( كلوريد الفينيل ) النانوية مع الطفلة المصرية العضوية ودراسة الخواص الميكانيكية والحرارية مالية النية

دعاء عبد الوارث الكومى'،أحمد مجدى مطاوع'، محمد سعيد درويش' ،سحر مصطفى أحمد'، سامية

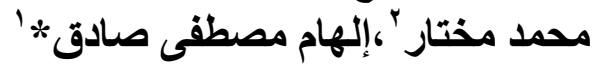

$$
\text { ا ـ قسم البتروكيماويات_معهد بحوث البترولـ مدينة نصر -القاهرة ـمصر }
$$

r-ققم الكيمياء- كلية البنات للآداب و العلوم و التربية- جامعة عين شمسـ- القاهرة- مصر

يهدف هذا البحث إلى تحضير متر اكبات بولي ( كلوريد الفينيل ) النانوية مع الطفلة المصرية العضوية النانوية المطورة بإستخدام اوكتا ديسيل امين هيدروكلوريدهو الملح الصوديومى لكل من حمض الاديييك وحمض السيباسيك بتقنية الإذابة. استخدم الميكروسكوب الإلكترونى النافذ وحيود الأشعة السينية والأشعة تحت الحمر اء لتقييم المتر اكبات الناتجة . أنشارت النتائج إلى تداخل بولي ( كلوريد الفينيل ) داخل طبقات

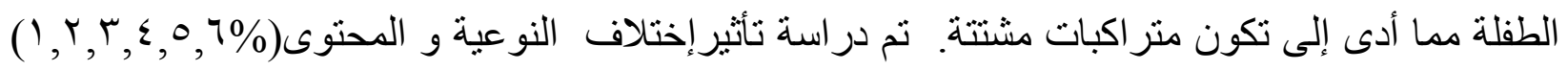
على المتر اكبات عن طريق قياس الخو اص الميكانيكية و الحر ارية. أظهرت النتائج تحسن و اضح فى الخو اص الميكانيكية والثبات الحرارى لمتراكبات الطفلة المطورة بالملح الصوديومى لحمض الادييك وحمض السيباسيك عند نسبة ؟\% بالمقارنة بالأوكتاديسيل أمين . 